\title{
Multilocus Sequence Types of Invasive and Colonizing Neonatal Group B Streptococci in Poland
}

\author{
Monika Brzychczy-Wloch ${ }^{a}$ Tomasz Gosiewski ${ }^{a}$ Malgorzata Bulanda ${ }^{b}$ \\ Departments of a Bacteriology, Microbial Ecology and Parasitology and ${ }^{\mathrm{b}}$ Infection Epidemiology, \\ Jagiellonian University Medical College, Krakow, Poland
}

\section{Key Words}

Group B streptococcus · Multilocus sequence typing ·

Newborns · Serotypes · Protein gene profiling .

Anti-microbial resistance

\begin{abstract}
Objectives: The present study aimed to investigate the molecular characterization of Streptococcus agalactiae (group B streptococcus; GBS) strains isolated from newborns with invasive neonatal infections and healthy newborns in Poland. Materials and Methods: Forty-two GBS isolates were characterized by combining different typing methods, i.e. multilocus sequence typing (MLST), molecular serotyping and protein gene profiling. Results: Using MLST, a total of 16 sequence types (STs) were identified, and among these, 11 were clustered into the following 5 clonal complexes (CCs): CC23 (20; 49\%), CC19 (7; 17\%), CC17 (4; 10\%), CC10 (4; 10\%) and CC1 $(1 ; 2 \%)$. A statistically significant relationship between ST-17 and invasive isolates $(p=0.0398)$ and ST-23 and colonizing strains $(p=0.0034)$ was detected. Moreover, 2 novel STs were detected (ST-637 and ST-638). Molecular serotyping showed that in the invasive isolates serotype III was predominant $(11 ; 50 \%)$, followed by serotypes II $(6 ; 27 \%), \mathrm{V}$ $(3 ; 14 \%)$ and la $(2 ; 9 \%)$. In healthy newborns, serotype III was also dominant $(12 ; 60 \%)$, followed by serotypes la $(4 ; 20 \%)$, II $(2 ; 10 \%), \mathrm{V}(1 ; 5 \%)$ and $\mathrm{Ib}(1 ; 5 \%)$. Protein gene profiling indi-
\end{abstract}

cated that the rib gene was predominant in the invasive strains $(11 ; 59 \%)$, followed by bca $(5 ; 22 \%)$, alp2 $(2 ; 9 \%)$, alp3 $(1 ; 5 \%)$ and epsilon $(1 ; 5 \%)$, while in colonizing strains the alp2 gene was most common (10; 50\%), followed by epsilon (5; $25 \%)$, rib (2; 10\%), bca $(2 ; 10 \%)$ and alp3 (1; 5\%). A statistically significant relationship was noted between the rib gene and invasive GBS ( $p=0.0329)$, whereas alp2 was related to the colonizing strains $(p=0.0495)$. Conclusions: The investigated GBS isolates originating from infections in newborns and healthy neonates represented serotype III in more than half of the cases and differed from one another in terms of resistance to macrolides, ST type affiliation and the presence of genes encoding surface proteins from the Alp family. Further comparative genetic research on a larger number of strains is necessary for epidemiological investigation and vaccine development.

(c) 2014 S. Karger AG, Basel

\section{Introduction}

Streptococcus agalactiae, also referred to as Lancefield group B streptococcus (GBS), is a significant pathogen in neonates and adults with predisposing conditions in the USA and Europe [1,2]. GBS in newborns can lead to early-onset diseases or late-onset diseases. Early-onset diseases develop during the first 7 days of life, while late-

\begin{tabular}{ll}
\hline KARGER & $\begin{array}{l}\text { () 2014 S. Karger AG, Basel } \\
1011-7571 / 14 / 0234-0323 \$ 39.50 / 0 \quad \text { Karger }\end{array}$ \\
$\begin{array}{l}\text { E-Mail karger@karger.com } \\
\text { www.karger.com/mpp }\end{array}$ & $\begin{array}{l}\text { This is an Open Access article licensed under the terms of the } \\
\text { Creative Commons Attribution-NonCommercial 3.0 Un- } \\
\text { ported license (CC BY-NC) (www.karger.com/OA-license), } \\
\text { applicable to the online version of the article only. Distribu- } \\
\text { tion permitted for non-commercial purposes only. }\end{array}$
\end{tabular}

Monika Brzychczy-Wloch, PhD

Chair of Microbiology, Department of Bacteriology, Microbial Ecology and Parasitology Jagiellonian University Medical College, 18 Czysta Street

PL-31121 Krakow (Poland)

E-Mail mbrzych@cm-uj.krakow.pl 
onset diseases occur after the first week to 90 days of age. The most frequent clinical form of neonatal GBS-caused infection is sepsis or pneumonia; a less frequent one is cerebrospinal meningitis [3].

$S$. agalactiae colonizes the genitourinary and lower gastrointestinal tract in 10-40\% of all pregnant women. Maternal colonization with GBS is the predominant risk factor for the development of invasive neonatal GBS disease [1-3]. GBS strains are subdivided according to typespecific capsular polysaccharides into 10 unique serotypes (Ia, Ib and II-IX) [2, 4]. This capsule has been recognized as one of the major virulence factors with an anti-phagocytic function [1]. The GBS pathogenicity varies between and within serotypes, with considerable variation in genetic content between strains. Particularly, the serotypes most often causing invasive infections in newborns are III, Ia and V [2, 5].

The best-characterized GBS protein antigens, which are significant virulence factors, belong to the alpha-like protein (Alp) family. They are called alpha-C protein, Rib, Alp2, Alp3, Alp4 and epsilon (Alp1) and are encoded by the $b c a$, rib, alp2, alp3, alp 4 and epsilon/alp1 genes, respectively [6]. Examination of the protein gene profile increases the potential for GBS subtyping $[7,8]$.

Multilocus sequence typing (MLST) has been described to be able to identify the emergence and spread of GBS clones and to study their genetic population structure worldwide [9-12]. Recently, the hypervirulent ST-17 clone, defined with the application of MLST and associated with late-onset diseases and a very high mortality rate in newborns with meningitis, has been of great interest [10-13].

There is limited knowledge regarding the epidemiology and molecular characterization of S. agalactiae strains isolated from newborns in Poland and Central-Eastern Europe, mainly due to a lack of supervision of these infections and failure to collect strains derived from neonates. Therefore, the aim of the present study was to determine and comparatively analyse the genotypes of GBS strains isolated from early-onset diseases in newborns and colonized neonates in Poland using different typing methods, such as molecular serotyping, protein gene profiling, antibiotic resistance phenotyping and gene profiling as well as MLST.

\section{Materials and Methods}

Study Population and Collection of Specimens

S. agalactiae strains were obtained from the collection of the Department of Bacteriology, Microbial Ecology and Parasitology of Jagiellonian University Medical College (Krakow, Poland) which was created from 2006 to 2010 within the framework of two projects financed by the Polish Ministry of Research and Higher Education [No.3PO5E08425 ( $\mathrm{n}=27)$ and NN401042337 ( $\mathrm{n}=15)$ ]. The samples were taken from 22 neonates with early-onset GBS disease as part of standard care, whereas samples from 20 healthy newborns were collected after receiving appropriate consent from their guardians. This study was approved by the Jagiellonian University Bioethical Committee.

The GBS strains originated from 3 neonatal wards from Southern $(n=27)$, Central $(n=12)$ and Northern $(n=3)$ Poland. A single isolate per patient was allowed. Altogether, 42 strains were obtained from newborns aged less than 7 days; 22 of these were from neonates with early-onset GBS disease, and 20 strains were isolated from colonized neonates without any signs or symptoms of infection. In 22 newborns with invasive neonatal infections, blood cultures were performed using Peds Plus Bactec 9120 media (Becton Dickinson, USA). Healthy newborns were tested for GBS colonization by taking swabs from the oral cavity during suction and from the external ear at $24-48 \mathrm{~h}$ of age [14]. The samples were placed in a non-nutrient Amies transport medium (Eurotubo, Spain) and within $2-4 \mathrm{~h}$ they were inoculated into a selective broth medium, i.e. $3 \mathrm{ml}$ Todd-Hewitt broth (Difco, USA) supplemented with $8 \mu \mathrm{g} / \mathrm{ml}$ gentamicin and $15 \mu \mathrm{g} / \mathrm{ml}$ nalidixic acid (Oxoid, UK), and then incubated overnight at $37^{\circ} \mathrm{C}$. Positive blood cultures and pre-incubated selective broth cultures were subcultured onto Columbia $5 \%$ sheep blood agar (Difco). The identification of GBS was performed first using a latex agglutination assay and an API STREP kit (bioMerieux, France). Molecular identification based on PCR with Sag59 and Sag190 species-specific primers (Genomed, Poland) for S. agalactiae was applied [18]. The tested GBS strains had been previously investigated for the presence of the hypervirulent ST-17 clone as previously described [13].

The characteristics of the serotypes were tested using serological a Group B Streptococcus GBS Serotyping Kit (ESSUM, Sweden). To verify the method, detection of the genes encoding capsular polysaccharides Ia, Ib and II-VIII was investigated using a multiplex PCR method with specific primers (Genomed) according to Poyart et al. [4].

Detection of the surface protein genes alp2, alp3, alp4, bca, epsilon and rib was investigated using a multiplex PCR with specific primers (Genomed) according to the procedure proposed by Creti et al. [7] and Gherardi et al. [2].

For antibiotic resistance, the minimum inhibitory concentrations (MIC) of penicillin, ampicillin, erythromycin, clindamycin and vancomycin were evaluated using Etest (Oxoid) as recommended by EUCAST [15]. The macrolide resistance phenotypes $\mathrm{CMLS}_{\mathrm{B}}$ (constitutive), $\mathrm{iMLS}_{\mathrm{B}}$ (inducible) and $\mathrm{M}$ were determined using a double-disc test with erythromycin $(15 \mu \mathrm{g})$ and clindamy$\operatorname{cin}(2 \mu \mathrm{g})$ (Oxoid). The erm(A), erm(B), erm(C) and mef(A/E) resistance determinants were detected by multiplex PCR with 4 adequate pairs of primers (Genomed) according to Sutcliffe et al. [16].

MLST analysis was performed as described by Jones et al. [10] using oligonucleotide primer pairs (Genomed) specific for the 7 housekeeping loci selected for GBS MLST. An online database (http://pubmlst.org/sagalactiae) was used to assign alleles to the 7 loci and each isolate was defined by their sequence type (ST). The eBURST program was used to group isolates into clonal complexes (CCs) whose members shared at least 6 of the 7 MLST loci [17]; otherwise, an ST was considered a singleton. Novel alleles of the housekeeping genes were amplified and sequenced twice and these 
Table 1. Characteristics of invasive and colonizing GBS strains isolated from neonates according to capsular serotype, Alp family gene and resistance determinant

\begin{tabular}{lccc}
\hline \multirow{2}{*}{$\begin{array}{l}\text { Investigated } \\
\text { features }\end{array}$} & \multicolumn{2}{c}{ Total } \\
\cline { 2 - 3 } & $\begin{array}{l}\text { invasive } \\
\text { strains }\end{array}$ & \\
\hline Capsular serotype & & & \\
Ia & $2(9)$ & $4(20)$ & $6(14)$ \\
Ib & $0(0)$ & $1(5)$ & $1(2)$ \\
II & $6(27)$ & $2(10)$ & $8(19)$ \\
III & $11(50)$ & $12(60)$ & $23(55)$ \\
V & $3(14)$ & $1(5)$ & $4(10)$ \\
Total & $22(100)$ & $20(100)$ & $42(100)$ \\
Gene from the Alp family & & \\
alp2 & $2(9)$ & $10(50)(\mathrm{p}=0.0495)^{*}$ & $12(28)$ \\
alp3 & $1(5)$ & $1(5)$ & $2(5)$ \\
bca & $5(23)$ & $2(10)$ & $7(17)$ \\
epsilon & $1(5)$ & $5(25)$ & $6(14)$ \\
rib & $13(58)$ & $2(10)(\mathrm{p}=0.0329)^{*}$ & $15(36)$ \\
Total & $22(100)$ & $20(100)$ & $42(100)$ \\
Erythromycin resistance gene & & \\
ermB & $6(27)$ & $0(0)(\mathrm{p}=0.0038)^{*}$ & $6(14)$ \\
Total & $22(100)$ & $20(100)$ & $42(100)$ \\
\hline
\end{tabular}

Values represent $\mathrm{n}(\%){ }^{*}$ Statistically significant $(\mathrm{p}<0.05)$.

profiles were named 'new' and added to the MLST database with a new ST number.

The potential relationship between invasive or colonizing GBS isolates and STs, CCs or serotypes was analysed.

\section{Statistical Analysis}

For statistical analysis of the frequencies and probability of coincidence, a $\chi^{2}$ test was used. When data were insufficient for the test demands, a $\mathrm{G}^{2}$ (likelihood ratio test) was used. Comparison of the antibiotic resistance between invasive and colonizing strains was made with a Wilcoxon test. $\mathrm{p}<0.05$ was considered statistically significant. Analyses were conducted using the SAS 9.1 package and SAS Enterprise Guide 3.0 (SAS Institute Inc., Cary, N.C., USA).

\section{Results}

\section{Serotypes of Neonatal GBS Strains}

In the group of 22 invasive GBS isolates, serotype III was predominant $(11 ; 50 \%)$, followed by serotypes II (6; $27 \%), \mathrm{V}(3 ; 14 \%)$ and Ia $(2 ; 9 \%)$. In the 20 healthy newborns colonized by GBS, serotype III was also predominant $(12 ; 60 \%)$, followed by serotypes Ia $(4 ; 20 \%)$, II (2; $10 \%), \mathrm{V}(1 ; 5 \%)$ and $\mathrm{Ib}(1 ; 5 \%)$. In the study population,

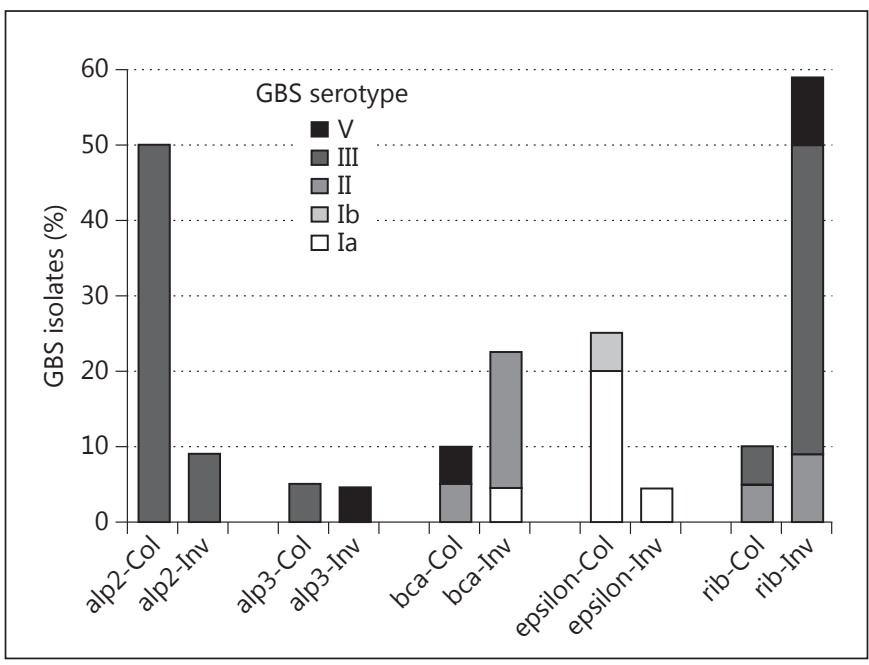

Fig. 1. Diversity of surface protein genes from the Alp family among the particular serotypes in GBS strains isolated from newborns with invasive neonatal infections and healthy newborns. $\mathrm{Col}=$ Colonizing GBS; Inv = invasive GBS.

serotypes IV and VI-VIII were not identified. No significant differences in serotype distribution were noted between the study groups of newborns (table 1).

\section{Surface Protein Genes of Neonatal GBS Strains}

One type of surface protein gene from the Alp family was found in each strain. In the invasive GBS isolates, rib was predominant $(13 ; 58 \%)$, followed by bca $(5 ; 23 \%)$, alp2 (2; 9\%), alp3 (1;5\%) and epsilon (1; 5\%). The most common gene in the colonizing GBS strains was alp $2(10$; $50 \%)$, followed by epsilon (5; 25\%), rib (2;10\%), bca (2; $10 \%)$ and alp3 (1;5\%). In this population of GBS isolates, the alp 4 gene was not found. Moreover, the relationships between the capsular polysaccharide serotype and surface protein genes in invasive and colonizing isolates were noted (fig. 1). A statistically significant relationship was observed between the rib gene and invasive GBS strains with the III serotype ( $\left.\chi^{2}=4.549 ; \mathrm{p}=0.0329\right)$ and the alp2 gene and colonizing GBS isolates with the III serotype $\left(\chi^{2}=3.630 ; \mathrm{p}=0.0495\right)($ table 1$)$.

\section{Resistance of the GBS Strains}

The values of $\mathrm{MIC}_{50}$ and $\mathrm{MIC}_{90}$ for penicillin, ampicillin, erythromycin, clindamycin and vancomycin are given in table 2. All GBS isolates were susceptible to penicillin, ampicillin and vancomycin. Resistant strains were found only in neonates with infections; $6(27 \%)$ of these invasive isolates were resistant to erythromycin $\left(\mathrm{G}^{2}=\right.$ 
Table 2. Distribution of MIC in invasive and colonizing GBS strains from neonates

\begin{tabular}{llll}
\hline Antibiotics & MIC & $\begin{array}{l}\text { MIC for colonizing } \\
\text { strains }(\mathrm{n}=20), \\
\mu \mathrm{g} / \mathrm{ml}\end{array}$ & $\begin{array}{l}\text { MIC for invasive } \\
\text { strains }(\mathrm{n}=22), \\
\mu \mathrm{g} / \mathrm{ml}\end{array}$ \\
\hline Penicillin & $\mathrm{MIC}_{50}$ & 0.06 & 0.06 \\
& $\mathrm{MIC}_{90}$ & 0.12 & 0.12 \\
\hline Ampicillin & $\mathrm{MIC}_{50}$ & 0.06 & 0.06 \\
& $\mathrm{MIC}_{90}$ & 0.078 & 0.06 \\
\hline Erythromycin & $\mathrm{MIC}_{50}$ & 0.06 & 0.06 \\
& $\mathrm{MIC}_{90}$ & 0.06 & $256(\mathrm{p}=0.0380)^{*}$ \\
\hline Clindamycin & $\mathrm{MIC}_{50}$ & 0.06 & 0.06 \\
& $\mathrm{MIC}_{90}$ & 0.06 & $256(\mathrm{p}=0.0090)^{*}$ \\
\hline Vancomycin & $\mathrm{MIC}_{50}$ & 0.5 & 0.5 \\
& $\mathrm{MIC}_{90}$ & 1 & 1 \\
\hline
\end{tabular}

* Statistically significant $(\mathrm{p}<0.05)$.

8.356; $\mathrm{p}=0.0038)$ and $5(23 \%)$ were resistant to clindamy$\operatorname{cin}\left(G^{2}=6.823 ; p=0.0090\right)$. Macrolide resistance was not attributable to a single serotype, ST or CC. Among the 6 resistant strains, the $\mathrm{CMLS}_{\mathrm{B}}$ phenotype was detected in 5 $(83 \%)$ cases and $\mathrm{iMLS}_{\mathrm{B}}$ in $1(17 \%)$. The ermB gene was present in all 6 macrolide-resistant strains. The ermA, erm $\mathrm{C}$ and $m e f(\mathrm{~A} / \mathrm{E})$ genes were not detected in the collected strains.

\section{MLST Analysis}

A total of 16 STs were identified for 42 of the examined strains. Among these, 11 were clustered into $5 \mathrm{CCs}$, the most prevalent of which was CC23 (20;49\%), followed by CC19 (7; 17\%), CC17 (4; 10\%), CC10 (4; 10\%) and CC1 $(1 ; 2 \%)$. The singletons identified were ST-22, ST-255 and ST-410; moreover, 2 novel STs were detected, i.e. ST-637 and ST-638 (table 3).

A statistically significant variability in the number of STs in invasive isolates $(\mathrm{n}=13)$ in relation to the colonizing strains $(n=6)$ was noted $\left(\chi^{2}=10.3 ; p=0.0013\right)$. A diverse population was found among the GBS isolates, with some exceptions, i.e. that ST-17 occurred only in invasive isolates with serotype III while ST-23 was more frequent in colonizing strains with serotype III (table 3; fig. 2).

Variability in the serotype distribution was observed within some of the STs. For instance, of the 16 isolates identified as ST-23, 11 were serotype III and 5 were sero- type Ia. Similarly, of the 5 isolates identified as ST-19, 3 were serotype II and 2 were serotype III. Conversely, all ST-17 isolates represented serotype III, and all ST-12 isolates belonged to serotype II.

\section{Discussion}

Our study demonstrated that the population structure of GBS isolates in Polish neonates is similar to the GBS population structures in other European countries and around the world $[18,19]$. S. agalactiae is a genetically diverse organism. Therefore, a combination of several molecular typing methods should be considered to provide a better understanding of the pathogenesis and epidemiology of GBS isolates [20]. Numerous epidemiological investigations have shown that the serotype distribution of GBS varies both geographically and over time [2, $4,5]$. In our study, serotype III was predominant in both study groups of neonates and represented $50 \%$ of the invasive GBS isolates and $60 \%$ of isolates from newborn colonization. Other serotypes in invasive strains were in sequence II, V and Ia and for colonizing strains Ia, II, V and $\mathrm{Ib}$. When comparing the present results with previous investigations on 169 GBS-positive pregnant women in whom serotype III was predominant in $35 \%$ of cases, followed by Ia, V, II, Ib and IV, we concluded that the current reported results are quite similar but with varying degrees of participation of individual serotypes [8]. The data obtained in relation to the serotype distribution correspond with the results of other European countries where serotypes Ia, II, III and V have been found in 80 $90 \%$ of all clinical isolates, while serotypes VI and VII-IX have seldom been observed [2,5]. Fluegge et al. [21] noted that serotype III was the most common in invasive and non-invasive GBS strains isolated from newborns, and it was significantly predominant in invasive isolates.

Surface protein antigens play an important role in the pathogenesis of GBS infection, and several of these antigens have been suggested as components of GBS conjugate vaccines $[1,6]$. Protein gene profiling increases the potential for GBS subtyping [7]. The association of the rib gene and serotype III has been confirmed by several reports $[2,21]$. In our study, the percentages of rib-positive isolates within serotype III strains varied significantly; in invasive isolates, the rib gene was detected in $59 \%$ of cases, while in colonizing strains rib was identified in $10 \%$ of cases. These results agree with previous studies which demonstrated that the rib gene was associated with invasive strains [22]. These findings may be evidence of an 
Table 3. Characteristic of the CCs and STs of invasive and colonizing GBS strains isolated from neonates according to virulence factors (serotypes and Alp genes) and resistance determinants (ermB gene)

\begin{tabular}{|c|c|c|c|c|c|c|}
\hline \multirow[t]{2}{*}{$\mathrm{CC}$} & \multirow[t]{2}{*}{ ST } & \multicolumn{2}{|c|}{ Strain type, $\mathrm{n}$} & \multirow{2}{*}{$\begin{array}{l}\text { Capsular } \\
\text { serotype }\end{array}$} & \multirow{2}{*}{$\begin{array}{l}\text { Gene from } \\
\text { the Alp } \\
\text { family }\end{array}$} & \multirow{2}{*}{$\begin{array}{l}\text { Erythromycin } \\
\text { resistance } \\
\text { determinant }\end{array}$} \\
\hline & & colonizing & invasive & & & \\
\hline CC1 (1) & ST-1 (1) & 0 & 1 & $\mathrm{~V}(1)$ & alp3 (1) & \\
\hline \multirow[t]{3}{*}{ CC10 (4) } & ST-10 (1) & 0 & 1 & II (1) & $b c a(1)$ & \\
\hline & ST-12(2) & 1 & 1 & II (2) & $b c a(2)$ & \\
\hline & $\overline{\text { ST-358 (1) }}$ & 0 & 1 & III (1) & $r i b(1)$ & ermB (1) \\
\hline CC17 (4) & ST-17 (4) & 0 & $4(\mathrm{p}=0.0398)^{*}$ & III (4) & $r i b(4)$ & \\
\hline \multirow[t]{4}{*}{ CC19 (7) } & ST-19 (5) & 2 & 3 & II (3) & & \\
\hline & & & & III (2) & rib (5) & ermB (2) \\
\hline & ST-106 (1) & 0 & 1 & II (1) & $b c a(1)$ & \\
\hline & ST-286 (1) & 0 & 1 & III (1) & rib (1) & \\
\hline \multirow[t]{6}{*}{ CC23 (20) } & ST-23 (16) & 13 & $3(\mathrm{p}=0.0034)^{*}$ & Ia (5) & alp2 (10) & \\
\hline & & & & III (11) & $\begin{array}{l}\text { alp3 (1) } \\
\text { epsilon (5) }\end{array}$ & \\
\hline & ST-220 (3) & 0 & 3 & Ia (1) & $b c a(1)$ & \\
\hline & & & & III (1) & $r i b(2)$ & \\
\hline & & & & $\mathrm{V}(1)$ & & \\
\hline & ST-249 (1) & 1 & 0 & III (1) & alp2 (1) & \\
\hline \multirow[t]{5}{*}{ Singleton (5) } & ST-22 (1) & 0 & 1 & II (1) & $b c a(1)$ & ermB (1) \\
\hline & ST-255 (1) & 1 & 0 & $\mathrm{Ib}(1)$ & epsilon (1) & \\
\hline & ST-410 (1) & 0 & 1 & III (1) & $r i b(1)$ & ermB (1) \\
\hline & ST-637 (1)** & 1 & 0 & $\mathrm{~V}(1)$ & $b c a(1)$ & \\
\hline & ST-638 (1)** & 0 & 1 & $\mathrm{~V}(1)$ & $r i b(1)$ & ermB (1) \\
\hline Not tested (1) & NT (1) & 1 & 0 & III (1) & alp2 (1) & \\
\hline
\end{tabular}

Numbers in parentheses represent the number of isolates. ${ }^{*}$ Statistically significant $(\mathrm{p}<0.05) .{ }^{* *}$ New sequence type.

important role of the Rib protein in invasive disease [21, 23]. Moreover, a statistically significant relationship between alp2-positive isolates within serotype III strains and colonizing status was detected. The noted relationship is interesting and has not been described by other investigators. In contrast, the most common Alp gene in GBS strains isolated from pregnant women from our previous report was epsilon, and it accounted for $26 \%$ of all cases [8].

For many years, GBS remained susceptible to penicillin, the recommended drug for the treatment and prophylaxis of infections caused by GBS. In the USA, for patients allergic to penicillin, the alternative drugs according to the 2002 recommendation of the Centers for Disease Control and Prevention (CDC) were macrolides and lincosamides [24]. However, in 2006 in the USA, $24.5 \%$ of invasive and $41.9 \%$ of colonizing GBS isolates were erythromycin resistant [26]. Due to this high level of erythromycin resistance, the CDC did not recommend erythromycin anymore in 2010 [25]. In Europe, the erythromycin resistance in GBS isolates from newborns and adults ranged from $10 \%$ in Portugal [27] to $16 \%$ in Poland [28] and $16.5 \%$ in Italy [2]. In the examined population of newborns, resistant strains were found only in neonates with invasive infections; $27 \%$ of these were resistant to erythromycin and $23 \%$ were resistant to clindamycin. Our results indicate a very high percentage of resistant strains in the study group of neonates.

Two principal resistance mechanisms are described for GBS: methylation of $23 \mathrm{~S}$ ribosomal RNA, determined by erm genes, and active drug efflux by pumps encoded by mef genes. Expression of erm genes is described as the $\mathrm{MLS}_{\mathrm{B}}$ phenotype $\left(\mathrm{cMLS}_{\mathrm{B}}\right.$ constitutive; $\mathrm{iMLS}_{\mathrm{B}}$ inducible), while expression of mef genes is called the M phenotype 
Fig. 2. Diversity of STs among particular serotypes in GBS strains isolated from newborns with invasive neonatal infections and healthy newborns.

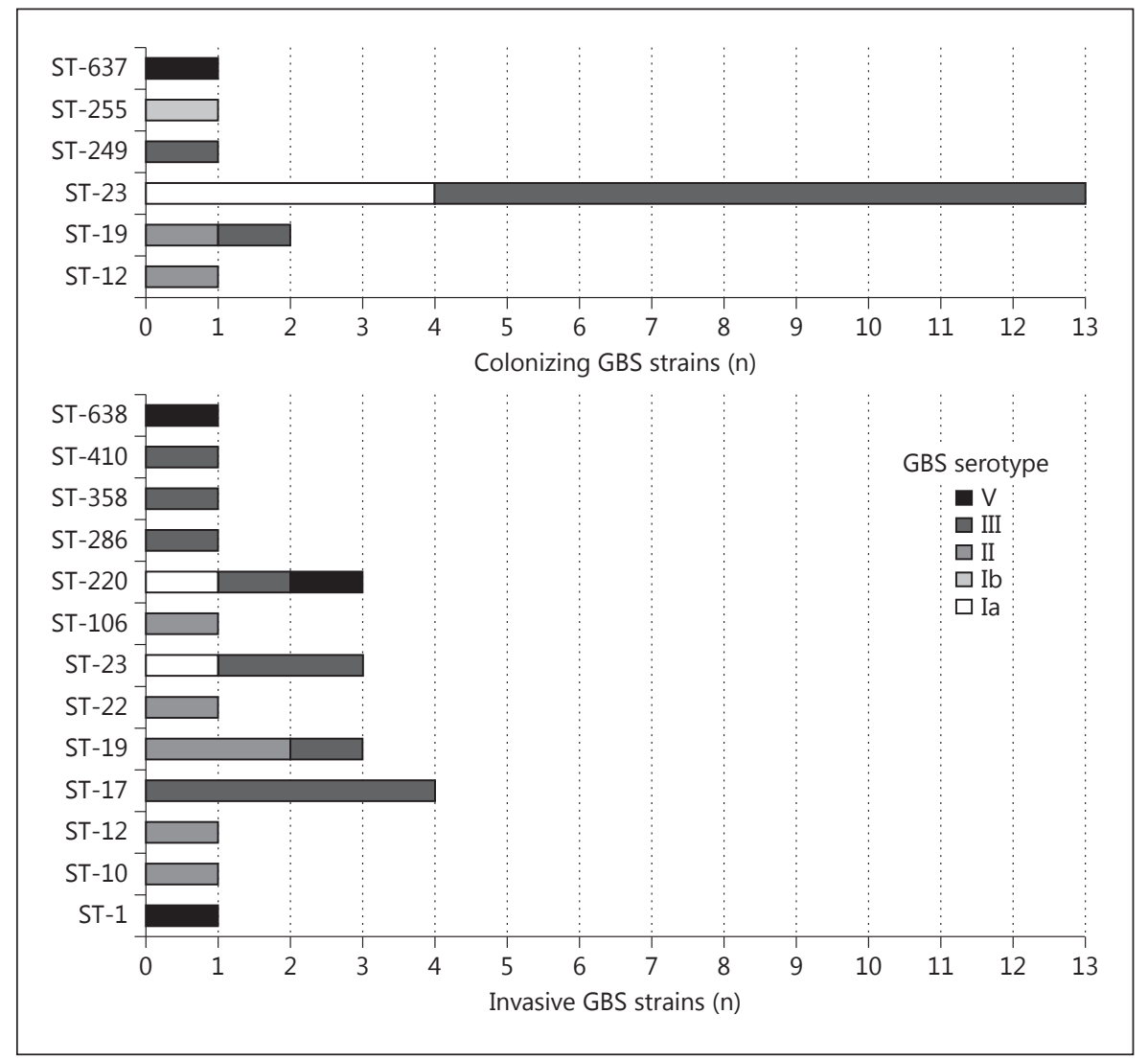

[2]. Among our invasive strains, the $\mathrm{cMLS}_{\mathrm{B}}$ phenotype was predominant in $83 \%$ of cases, followed by $\mathrm{iMLS}_{\mathrm{B}}$ in $17 \%$, and the presence of the ermB gene was detected in all of the cases. Similar results have been noted by other investigators. For example, Sadowy et al. [9] reported that the most prevalent determinant of resistance was ermB, usually located on the Tn3872-like transposon.

MLST has become the conventional method for determining the population structure of GBS, and it has been applied to the molecular epidemiology of $S$. agalactiae infections by several investigators $[9,10,19]$. To date, 5 main CCs, i.e. CC1, CC10, CC23, CC19 and CC17, have been identified, emphasizing the diversity of S. agalactiae in humans $[9,19]$. In our study, approximately $86 \%$ of the invasive isolates and $85 \%$ of the colonizing strains could be grouped into 1 of the 5 CCs (CC23, CC19, CC17, CC10 or CC1). These 5 CCs have also been highly widespread in other GBS collections, i.e. from Italy [2], Sweden [29], the USA [19] and Taiwan [30]. Sadowy et al. [9] reported that GBS isolates represented 30 different STs grouped into 4 CCs, i.e. CC1, CC17, CC19, and CC23, that constituted $98.2 \%$ of all the studied isolates.
In our study, CC17 occurred only in invasive isolates with serotype III and rib, while CC23 was more frequently present in colonizing strains with serotype III and alp2. Similarly, a study by Bohnsack et al. [19] demonstrated that CC17 was strongly correlated with serotype III and invasive infection, whereas CC23 strains were predominant in $98 \%$ of cases among serotype Ia strains that colonize human neonates. In contrast, in a German-based study, MLST of non-invasive serotype III isolates from neonates in whom sepsis was suspected but whose blood cultures were sterile revealed that ST-389, which belongs to CC19, was predominant [21].

The hypervirulent clone ST-17 represents successful invasive clones which belong to the complex CC17 and are responsible for causing invasive infections in newborns, and it is now considered the most important type of ST worldwide [12, 13, 18, 29]. This clone is isolated from neonates with both early-onset diseases and lateonset diseases and the majority of cases present in the form of meningitis, with a high mortality rate $(70 \%)[19$, 29]. Straková et al. [12] identified the ST-17 clone in $85 \%$ of cerebrospinal fluid isolates ( 6 out of 7 ) but only in $32 \%$ 
of blood isolates. In our study, the hypervirulent clone ST-17 was detected in 4 cases (18\%) of early sepsis developing during the first day of life.

Similarly to the findings of Luan et al. [29], within some of the STs, we noticed variability in the serotype distribution. For example, out of the 16 isolates identified as ST-23, 11 were serotype III and 5 were serotype Ia; moreover, 3 out of 3 ST-220 isolates expressed 3 different serotypes, i.e. Ia, III and V. These results confirmed that the horizontal transfer of capsular genes exists in the GBS population. Indeed, the level of capsular switching appears to be high in $S$. agalactiae strains and the exchange of capsule polysaccharide genes between isolates with different genetic backgrounds occurs without restrictions to certain genetic lineages [29].

A limitation of our study is the small number of collected strains from neonates. However, due to a complete lack of similar analyses from our country, we strongly believe that our results are unique from the Polish perspective and support important information about neonatal GBS isolates. Admittedly, Sadowy et al. [9] conducted studies on the population structure of
GBS in Poland, but the analysis involved strains isolated from different clinical materials, mainly from adults.

\section{Conclusion}

The investigated GBS isolates originating from infections in newborns and healthy neonates represented serotype III in more than a half of the cases and differed from one another in terms of resistance to macrolides, ST type affiliation and the presence of genes encoding surface proteins from the Alp family. Further comparative genetic research on a larger number of strains is necessary for epidemiological investigation and vaccine development.

\section{Acknowledgements}

This study was supported by a grant from the Polish Ministry of Research and Higher Education (No. N N401 042 337). This study was approved by Jagiellonian University Bioethical Committee decision No. KBET/143/B/2007.

\section{References}

1 Johri AK, Paoletti LC, Glaser P, et al: Group B streptococcus: global incidence and vaccine development. Nat Rev Microbiol 2006;4:932942.

-2 Gherardi G, Imperi M, Baldassarri L, et al: Molecular epidemiology and distribution of serotypes, surface proteins and antibiotic resistance among group B streptococci in Italy. J Clin Microbiol 2007;45:2909-2916.

- 3 Heath PT, Schuchat A: Perinatal group B streptococcal disease. Clin Obstet Gynecol 2007;21:411-424.

-4 Poyart C, Tazi A, Réglier-Poupet $\mathrm{H}$, et al: Multiplex PCR assay for rapid and accurate capsular typing of group B streptococci. J Clin Microbiol 2007;45:1985-1988.

5 Persson E, Berg S, Trollfors B, et al: Serotypes and clinical manifestations of invasive group B streptococcal infections in western Sweden 1998-2001. Clin Microbiol Infect 2007;10: 791-796.

-6 Lindahl G, Stalhammar-Carlemalm M, Areschoug T: Surface proteins of Streptococcus agalactiae and related proteins in other bacterial pathogens. Clin Microbiol Rev 2005;18: 102-127.

7 Creti R, Fabretti F, Orefici G, et al: Multiplex PCR assay for direct identification of group B streptococcal alpha-protein-like protein genes. J Clin Microbiol 2004;42:1326-1329.
8 Brzychczy-Wloch M, Gosiewski T, Bodaszewska-Lubas $\mathrm{M}$, et al: Molecular characterization of capsular polysaccharides and surface protein genes in relation to genetic similarity of group B streptococci isolated from Polish pregnant women. Epidemiol Infect 2012;140: 329-336.

9 Sadowy E, Matynia B, Hryniewicz W: Population structure, virulence factors and resistance determinants of invasive, non-invasive and colonizing Streptococcus agalactiae in Poland. J Antimicrob Chemother 2010;65:1907-1914.

10 Jones N, Bohnsack JF, Takahashi S, et al: Multilocus sequence typing system for group B streptococcus. J Clin Microbiol 2003;41: 2530-2536.

11 Manning SD, Springman AC, Lehotzky E, et al: Multilocus sequence types associated with neonatal group B streptococcal sepsis and meningitis in Canada. J Clin Microbiol 2009; 47:1143-1148.

12 Straková L, Musílek M, Motlová J: Multilocus sequence types in Czech neonatal GBS strains from 2004 to 2008. Epidemiol Microbiol Immunol 2010;59:45-47.

13 Brzychczy-Wloch M, Gosiewski T, Pawlik D, et al: Occurrence of the hypervirulent ST-17 clone of Streptococcus agalactiae in pregnant women and newborns. Przegl Epidemiol 2012;66:395-401.
14 Strus M, Pawlik D, Brzychczy-Wloch M, et al: Group B streptococcus colonization of pregnant women and their children observed on obstetric and neonatal wards of the University Hospital in Krakow, Poland. J Med Microbiol 2009;58:228-233.

15 European Committee on Antimicrobial Susceptibility Testing: Breakpoint tables for interpretation of MICs and zone diameters version 2.0, valid from 2012-01-01. http:// www.eucast.org/fileadmin/src/media/PDFs/ EUCAST_files/Disk_test_document/EUCAST_breakpoints_v_2.0_120101.pdf.

16 Sutcliffe J, Grebe T, Tait-Kamradt A, et al: Detection of erythromycin-resistant determinants by PCR. Antimicrob Agents Chemother 1996; $40: 2562-2566$.

17 Feil EJ, Li BC, Aanensen DM, et al: eBURST: inferring patterns of evolutionary descent among clusters of related bacterial genotypes from multilocus sequence typing data. J Bacteriol 2004;186:18-30.

18 Martins ER, Pessanha MA, Ramirez M, et al: Analysis of group B streptococcal isolates from infants and pregnant women in Portugal revealing two lineages with enhanced invasiveness. J Clin Microbiol 2007;45:32243229. 
19 Bohnsack JF, Whiting A, Gottschalk M, et al: Population structure of invasive and colonizing strains of Streptococcus agalactiae from neonates of six US academic centers from 1995 to 1999. J Clin Microbiol 2008;46:285291.

-20 Udo EE, Boswihi SS, Al-Sweih N: Genotypes and virulence genes in group B streptococcus isolated in the Maternity Hospital, Kuwait. Med Princ Pract 2013;22:453-457.

21 Fluegge K, Wons J, Spellerberg B, et al: Genetic differences between invasive and noninvasive neonatal group B streptococcal isolates. Pediatr Infect Dis J 2011;30:1027-1031.

22 Persson E, Berg S, Bevanger L, et al: Characterisation of invasive group B streptococci based on investigation of surface proteins and genes encoding surface proteins. Clin Microbiol Infect 2008;14:66-72.
23 Stålhammar-Carlemalm M, Stenberg L, Lindahl G: Protein rib: a novel group B streptococcal cell surface protein that confers protective immunity and is expressed by most strains causing invasive infections. J Exp Med 1993; 177:1593-1603.

24 Schrag SJ, Zell ER, Lynfield R, et al: A population-based comparison of strategies to prevent early-onset group B streptococcal disease in neonates. N Engl J Med 2002;25:233-239.

25 Verani JR, McGee L, Schrag SJ: Prevention of perinatal group B streptococcal disease: revised guidelines from CDC, 2010. MMWR Morb Mortal Wkly Rep 2010;59:1-32.

26 Borchardt SM, DeBusscher JH, Tallman PA, et al: Frequency of antimicrobial resistance among invasive and colonizing group B streptococcal isolates. BMC Infect Dis 2006;6:57.
27 Figueira-Coelho J, Ramirez M, Salgado MJ, et al: Streptococcus agalactiae in a large Portuguese teaching hospital: antimicrobial susceptibility, serotype distribution, and clonal analysis of macrolide resistant isolates. Microb Drug Resist 2004;10:31-36.

28 Brzychczy-Wloch M, Gosiewski T, Bogdaszewska $\mathrm{M}$, et al: Genetic characterization and diversity of Streptococcus agalactiae isolates with macrolide resistance. J Med Microbiol 2010;59:780-786.

29 Luan SL, Granlund M, Sellin M, et al: Multilocus sequence typing of Swedish invasive group B streptococcus isolates indicates a neonatally associated genetic lineage and capsule switching. J Clin Microbiol 2005;43: 3727-3733.

30 Tien N, Ho CM, Lin HJ, et al: Multilocus sequence typing of invasive group B streptococcus in central area of Taiwan. J Microbiol Immunol Infect 2011;44:430-434. 